\title{
Impact of Selected Countries Exports of Commercial Services on World Exports Commercial Services
}

\author{
Ashiq Hussain ${ }^{1}$, Muhammad Ajmair ${ }^{2}$ \\ ${ }^{1}$ Director, Mian Muhammad Bukhash Public Library, Mirpur AJK, Pakistan \\ ${ }^{2}$ Assistant Professor, Mirpur University of Science and Technology, Mirpur AJK, Pakisatn
}

\begin{abstract}
Commercial services are becoming an increasingly important component of world trade. The past two decades have seen exciting changes with developing countries emerging as exporters of services. This paper is an attempt to investigate the impact of selected countries exports commercial services o $n$ World commercial services exports. For this purpose I used the secondary data for 11 year from 2001 to 2011. The data was taken in millions; it was taken as it is according to WTO statistics. Multiple regression time series techniques were applied to estimate the relationship. In result developed countries united State, Netherlands, Italy and France are negatively influencing the world exports of commercial services. Because dependent variable has negatively sign (with its dependent variable coefficient $C$ ), so this relationship is negatively correlated to the independent variables united State, Netherlands, Italy and France .p-value 0.0000 and highest $R$-square value $99.9 \%$.
\end{abstract}

Keywords: Commercial Services, Services Exports, World Trade, WTO, Multiple Regressions

\section{Introduction}

The service sector makes an important contribution to gross domestic product (GDP) in most countries, providing jobs, inputs and public services for the economy. Trade in services can improve economic performance and provide a range of traditional and new export opportunities.

Significant contribution to GDP and job creation, and provides crucial inputs for the rest of the economy, thus having a significant effect on the overall investment climate, which is an essential determinant of growth and development. Some service sectors, such as the health, education, water and sanitation sectors, are also directly relevant to achieving social development objectives. The service sector accounts for a significant proportion of GDP in most countries, including low-income countries, where it frequently generates over $50 \%$ of GDP. The process of development usually coincides with a growing role of services in the economy (alongside a reduced role for agriculture). Thus, services constitute an increasing percentage of GDP in nearly all developing countries. Services contributed $47 \%$ of growth in Sub-Saharan Africa over the period 2000 2005, whereas industry contributed $37 \%$ and agriculture only 16\%. Recent growth in Africa owes to services as much as natural resources or textiles (even in countries benefiting from trade preferences in these products). The question is not whether to move into services, but how and at what speed to move into services. Many services are key inputs to all or most other business, e.g. infrastructure services such as energy, Telecommunications and transportation; financial services, which facilitate transactions and provide access to finance for investment; health and education services, which contribute to a healthy, well trained workforce; and legal and accountancy services, which are part of the institutional framework required to underpin a healthy market economy. These service sectors are thus a key part of the investment climate and can have a much wider impact on overall business performance and the level of investment, and hence growth and productivity in the economy.

Trade in services refers to the sale and delivery of an intangible product, called a service, between a producer and consumer. Trade in services takes place between a producer and consumer that are, in legal terms, based in different countries, or economies, this is called International Trade in Services.

The term services cover a wide range of intangible and heterogeneous products and activities that is difficult to encapsulate within a simple definition. Services are either the result of a production activity that changes the conditions of the consuming units (transformation services), or facilitate the exchange of products or financial assets (margin services). They can cover transport, telecommunication and computer services, construction, financial services, wholesale and retail distribution, hotel and catering, insurance, real estate, health and education, professional, marketing and other business support, government, community, audiovisual, recreational, and domestic services.

Services have a significant impact on growth and efficiency across a wide range of industries and overall economic performance.

For instance, sectors such as transport, Telecommunications and financial services are key determinants of the conditions in which persons, merchandise, services and capital flow. Another illustration of the servicese major role is environmental services, which contribute to sustainable development by alleviating negative impacts of economic activities. Services currently represent more than two thirds of World Gross Domestic Product (GDP). The share of services value added in GDP tends to rise significantly with the countries" level of income, standing at $73 \%$ on average in high income countries (77\% in the United States), against 


\section{International Journal of Science and Research (IJSR) \\ ISSN (Online): 2319-7064}

Index Copernicus Value (2013): 6.14 | Impact Factor (2015): 6.391

$54 \%$ and $47 \%$ respectively in middle- and low- income countries.

Even in the latter group, the production of services is generally a core economic activity, whose contribution to GDP is above that of both industry and agriculture. Significant differences however exist between countries within the same income group, as for example for India and Nigeria - two middle income countries whose respective shares of services in GDP are $54 \%$ and $27 \%$, or Kenya and Liberia - two low income countries whose shares are $54 \%$ and $22 \%$.The current importance of servicese value added follows decades of sustained growth of contribution of the services sector to GDP, which is also mirrored in employment statistics. Looking at developments over the 1997-2007 period, a significant shift of employment from the agriculture and industry sectors to the services-producing sector can be observed.

Services' contribution to total employment gained on average 5 percentage points in high income countries. Available information suggests that the increase was also sharp on average in most middle income countries. For instance Mauritius and Malaysia registered growths of about 8 percentage points, and for some of these middle income countries (e.g. Mongolia, Nicaragua, Turkey) the growth was over 10 percentage points. Employment data further confirm the importance of the services sector which is accounting for more than half of the employment in many countries (up to $78 \%$ in the United State)

Commercial service is General term for large online services. These services are like special clubs that require membership dues. Besides providing access to the internet, commercial services have lots of content, games, and chat rooms that are available only to members.

World exports of commercial services amounted to US\$ 3,350 billion in 2009 , after growing on average at around $7.9 \%$ per year in value terms since 1980. Trade in commercial services grew faster than b) Trade in commercial services 1 trade in goods (6.6\% on average) during this period, increasing its share in total world trade by 6 percentage points. In 2009, the share of services in world trade reached $21 \%$ that is 2 percentage points up from the previous year, as the decline in global trade in services was considerably less pronounced than that of goods.

The share of services in world trade contrasts with the central contribution of services production in domestic economies. Due to their intangible nature, trade in services is inherently subject to more constraints than trade in goods. While a (tangible) good may be produced, stored, moved and consumed at different places and times, the delivery of a (intangible) service is seldom dissociated from its production and its consumption, requiring the proximity of the supplier and the customer. For instance, hairdressers and their clients need to be physically close for a haircut.

The need for proximity for supplying many services has led producers to supply their products through a commercial presence abroad, i.e. the establishment of foreign affiliates. This form of international supply of services (which is not covered in the chart presented above) is considered at least as important in value terms as "conventional" international trade in services between residents and non-residents

Share in total exports of commercial services, 2011

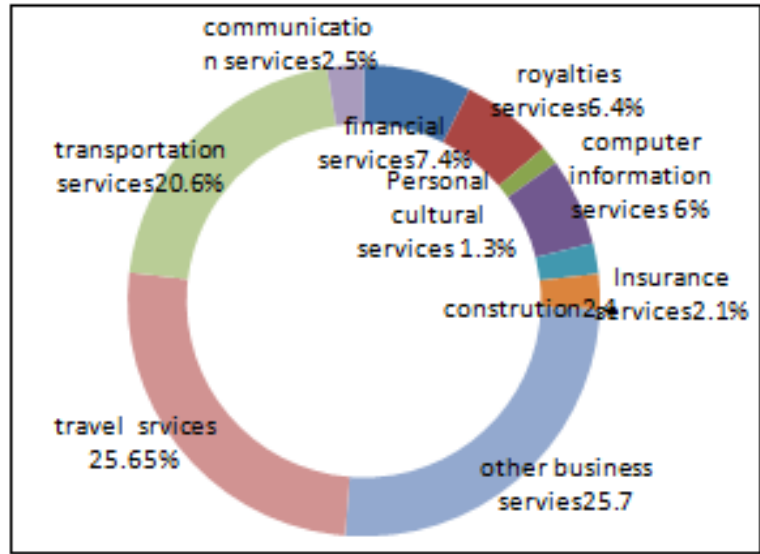

Half of world exports of commercial services consisted of travel receipts and other business services in 2011. Transportation services accounted for 20.6 per cent, down from 22.7 per cent in 2005 .

Exports of financial services represented 7.4 per cent of global exports of commercial services in 2011, followed by royalties and license fees with 6.4 per cent. Computer and information services accounted for 6.0 per cent of world exports of commercial services, up from 4.0 per cent in 2005.

Other sectors had a much smaller share in commercial services exports. Insurance services, construction and communications services accounted for between 2.1 per cent and 2.5 per cent in 2011. Personal cultural and recreational services, which include audio-visual services, had the smallest share with 1.3 per cent of global commercial services exports

The main objectives of the proposed research are:

To examine the role of exports of commercial services of selected countries in the world commercial services exports. To find out the way in order to foster the sustainable development of services sector.

\section{Hypothesis of the study}

The proposed study aims at testing the hypothesis that the commercial sectors play a vital role in economies and world commercial services exports.

\section{Statement of the problem}

As an evident from the above the commercial services exports of some selected countries is effect the world commercial exports services.

\section{Organization of the study}

Chapter 1describe the present scenario of commercial services in the world, It also includes the objective of the study. Chapters 2 include the literature reviewed, Chapter 3 includes the methodology, and Chapter 4 includes the result of the study. Chapter 5 includes conclusion and recommendation of the study. 


\section{International Journal of Science and Research (IJSR) ISSN (Online): 2319-7064}

Index Copernicus Value (2013): 6.14 | Impact Factor (2015): 6.391

\section{Review of Literature}

(Carolina Lennon2006) studied the increasing importance of services in national economies (accounting for about 50-70 $\%$ of internal product), in global economy (accounting for the $20 \%$ of global trade) and in public opinion (i.e. US Concern about Mexican workers due to migration laws or the case of the "polish plumbers" in France at the time of European Constitution referendum) there is no economic consensus about the way in what services should be considered in trade liberalization analyses. The double purpose of this paper is; first, to empirically determine to what extent trade in services differs from trade in goods and, second, to explore for potential complementarities between bilateral trade in goods and bilateral trade in services. For our first goal we regress a set of equations derived from the gravitational model and for the second we instrument bilateral trade for both services and goods in order to analysis potential causalities of each type of flow in the other. Main results show that "bilateral trust and contract enforcement environment", "networks", "labor markets" and "technology and technology of communication" have higher impact on service trade than on trade in goods; finally, after incrementing for endogeneity, we found that bilateral trade in goods explains bilateral trade in services: the resulting estimated elasticity is close to 1 .

Reciprocally, though in a lower extent, bilateral trade in services affects positively bilateral trade in goods: a $10 \%$ increase in trade in services raises traded goods by $4.6 \%$.

(HolgerBreinlich et al 2009) studied international trade in services, using unique .rm-level data on service exports and imports from the world's second largest service exporter, the United Kingdom. Less than $10 \%$ of .rams trade in services but they can be found in all sectors of the UK economy. While the service sector accounts for over $80 \%$ of total exports and imports, the frequency and trade intensity of service traders is often higher in sectors such as high-tech manufacturing. Service traders are bigger, more productive and are more likely to be foreign owned or part of a multinational enterprise. Trade premia are smaller for service traders than for goods traders, with the exception of skill intensity which is higher for service traders. There are also significant deference between exporters and importers of services. Service exporters are smaller and less capital intensive but more productive and skill intensive than service importers. We show that most .rms only export or import a single type of service and trade with a small number of countries. Trade volume, employment, turnover and value added are highly concentrated among a small group of .rms which trade with many countries and/or in many types of services. Interestingly, trade is also concentrated within .rms. The top export and import destinations make up $70 \%$ of the average .ram's total trade and the top services type around $90 \%$. We also decompose the cross-sectional variation in .ram exports and imports of services into the extensive and intensive margins of trade and .nd that the intensive margin accounts for around $70 \%$ of the total variation.

(Tadayuki Miyamoto et al.2002) studied the world trade statistics emphasis rapid globalization of commercial services (CS) and underpin the criticality of a country's positioning strategy in the growing world CS market. Drawing on trade statistics of 77 countries, this paper assesses configurations and composes a matrix of CS internationalization as a framework to classify and map countries in the world CS market. Overall the study differentiates between countries based on the structures of country export and CS trade ratios. Key findings are that there are the two distinctive patterns of country CS. Internationalization among the G7 countries, and that the country CS trade success (measured by CS trade balance per capita) appears to be determined by a country's CS internationalization mode.

Mr. Alberto Gabriele (2006) studied the main trends in international trade in services during the last two decades of the last century, and explores quantitatively the nexus between GDP growth and exports of services, focusing particularly on the role of developing and transition countries. The Introduction briefly exposes some of the shortcomings and methodological problems affecting IMF Balance of Payments (BOP) statistics on international trade in services. The descriptive statistical analysis in Section 2 shows that services exports have been the most dynamic component of world trade and that the world market share of developing countries has been on the rise. However, a generalized deceleration in the expansion of world trade in services occurred in the late 1990s. The growth rate of services exports from developing countries slowed down, and their ability to import services also declined, with a negative impact on their development perspectives.

He focuses on the main exporters in each of the services sub-sectors among developing and transition countries. Most of them are either large semi-industrialized Asian countries or European transition countries that have achieved or conserved a relatively high level of industrial and technological development with respect to the rest of the non-developed world, but there are also cases of other developing countries showing a strong tendency to specialize in one or a few specific services sub-sectors. Correlation analysis in Section 4 shows that, in the long run, services exports do have a positive impact on GDP growth in developing countries. Yet, for developing countries the services exports/GDP growth nexus is weaker than in the case of developed countries. Moreover, in most developing regions, the growth-enhancing impact of exports as a whole appears to have declined in the 1990s, although this decline appears to be due more to the merchandise component of exports than to the services component.

In the Conclusions, a tentative explanation for the aforementioned results is proposed. Export-oriented services activities in developing countries are often under the control of a foreign economic agent and tend to be poorly integrated with the rest of the domestic economy. Thus, their potential as engines for growth is relatively weak. Moreover, many previously inward-oriented developing countries, under conditions of financial duress, have diverted resources towards exports as a goal per se, rather than in the framework of a comprehensive long-term growthmaximizing strategy. Such opening-up reforms have ended up facing diminishing returns 


\section{International Journal of Science and Research (IJSR) \\ ISSN (Online): 2319-7064}

Index Copernicus Value (2013): 6.14 | Impact Factor (2015): 6.391

Rolf J. Lang hammer(2000) studied the departs from the perception that trade in services in general and developing countries' exports in services in particular are dynamic segments of world trade. Both total trade data as well as US import trade figures do not support this perception. Success episodes such as the recent increase in Indian computer and data processing services are found to be outliers.

Instead, developing countries continue to rely on relatively slowly growing exports of relatively labor-abundant consumer services relating to movements of goods and persons. Thus, they have not yet benefited from innovations in the information technology sectors providing a growth momentum for producer services. Given the link between goods production and goods distribution, successful exporters of manufactures mostly overlap with successful exporters of services. It is shown that the majority of exemptions from MFN treatment concentrate on such consumer services thus impeding developing countries' export growth. In view of the vague character of commitments negotiated in the General Agreement on Trade in Services, the paper argues that for the time being over proportionate growth of service exports from developing countries will remain limited to country episodes, but will not have the same wide country coverage as growth of manufactured export

(Shahbaz Nasir) According to shahbaz Advancements in information and communications technologies (ICTs) have increased the possibilities for trade in modern services and many emerging economies are participating increasingly in these new trade activities. This paper explains the sources of increasing modern services exports from emerging countries, and the opportunities for future growth. The paper reviews selected theories and empirical work in the trade literature to explain the underlying reasons for these increasing exports. The paper finds that emerging countries are well placed for modern services exports due to the increasing services outsourcing that offers substantial benefits to importing economies, and the comparative advantage of emerging countries, which has been facilitated by declining trade costs and advancements in ICTs. Nonetheless, only few developing countries could fully exploit these opportunities.

(Bhagwati 2004) focuses on the literature related to cross border trade and outsourcing of services. This study focuses on modern services, including IT and IT enabled services. These services are delivered largely through the cross-border mode of trade, and outsourcing has contributed to the increase in these exports from emerging countries

(Markusen 2007) presents the case for outsourcing of skilled labor jobs from developed countries to emerging countries. He builds his framework on the idea that the availability of skilled engineers in India or some other developing countries may be in abundance but these skilled persons may not have anything to do at home. Therefore, their relative prices may be low in skill scarce nations. This argument provides good support for the outsourcing of skilled jobs to developing countries in a factor-proportions or HO approach.
(Copeland and Mattoo 2008) explain trade in services different from those that explain trade in goods? Broadly speaking, the two major explanations for trade between countries also apply to service trade and can be extended to include trade through different modes. First, the theory of comparative advantage sees trade as inter industry and the result of fundamental differences between countries. In the case of services, as for goods, differences in technology and relative endowments (including factors of production as well as institutions and infrastructure) determine comparative advantage. Thus, Kenya exports certain skill-intensive professional services to other African countries because it is relatively well endowed with skilled labor, and the United States exports satellite Launch services to other countries because it is relatively well endowed with capital and the relevant technology.

Differences in determinants are not static and may evolve over time depending on the policy and other choices a country makes. The second explanation for intra industry trade between countries emphasizes the twin features of (a) consumers' love of variety and (b) producers' gains from specialization in specific varieties caused by increasing returns to scale or agglomeration.

Many firms exist because they have specialized knowledge, distribution and supply networks, and differing reputations for quality and reliability. Thus, both the United States and Europe produce and sell banking services to each other, because their respective banks - ranging from the Bank of America to UBS - have specialized in slightly differentiated services that appeal to different U.S. and European consumers.

( Reeti Gupta 2012) studied the India espoused an outward orientation in July 1991 and instigated a gradual process of liberalization both in domestic sector as well as in foreign trade sector. During the two decades of reforms regime the role of foreign trade grown in India and remarkable changes came in its trade scenario. A noteworthy change during the post reforms regime is that India penetrates in global markets more rapidly for services trade than for goods trade. Considering this, on the eve of completion of second decade of reform, this study attempts to understand the dynamics and structure of India's commercial service exports in order to trace the impact of trade policy reforms on their composition. This study is exploratory in nature and utilizes secondary sources of data to draw out the inferences. After a detailed exploration of data the study finds out steep rise in the share of commercial service exports in total trade of India and a structural shift in its structure during the post reforms regime. The study advocates more entry level and domestic level reforms along with diversification in commercial service exports to gain further momentum and supports trade openness to gain competitive advantage for commercial service trade in the global market.

(Sujinda Chemsripong, 2008) Explain the services sector plays an important role in the economic transformation of a country. The growing tradability of services provides new challenges and opportunities to Thailand's services industries. Underpinning these challenges and opportunities is the competitiveness and export structure of the services 


\section{International Journal of Science and Research (IJSR) \\ ISSN (Online): 2319-7064 \\ Index Copernicus Value (2013): 6.14 | Impact Factor (2015): 6.391}

sector. Thailand's current services export structure is a manifest of its relative specialization based upon given resources, activities, and strategies. To assess the competitiveness of Thailand's services sector, the paper computes the Revealed Comparative Advantage (RCA) indices of Thailand's transport, travel, insurance, and financial services. Specifically, the paper evaluates the shifting export competitiveness of Thailand's services industries in the context of ASEAN-5. Among other factors, export competitiveness in services depends upon the height of market access barriers, targeted under GATS and AFAS. The paper analyses Thailand's service liberalization scorecard in terms of its commitments to liberalize trade in services. Acknowledging the fact that the domestic, regional, and global trading environment is a necessary but not a sufficient condition for services firms to participate in international trade, the paper signifies the need to work on various industry, firm, and mode-specific factors that underpin competitiveness of the Thai services industry

(Susanna Lundstrom Gable et at 2011) Explain that the technology has changed the nature of service activities and made them more productive, tradable and fragmented in the global supply chain. Has Europe's growth been benefiting from the ongoing globalization of services? Services dominate growth in EU-15 countries and, to a lesser extent, in New Member States (NMS) and Accession (ACC) countries. Except in the ACC region, Europe has maintained specialization in service exports. Service productivity, tradability, and exports of modern services are high in EU15, growing fast in NMS while at a lower pace in ACC. Service export sophistication is important for growth across the region, but especially in NMS.

(Millicent E Poole et al.2003) According to that there is no doubt that the service sector is by far the largest sector in the Australian economy. The service sector contributes some $80 \%$ in value added terms and $81 \%$ of employment. It is the sector which will provide the greatest opportunities in employment growth with export of services becoming increasingly vital to the future of the Australian economy. However, the service sector is not easily defined. On the one hand, for example, as a considerable Proportion of what is normally classified under agriculture, manufacturing or mining is of a service nature. On the other hand, the differentiation between a good and a service is also by no means clear. The sector is diverse ranging from highly technical services, such as in developing computer software, to the more mundane, such as hospital cleaning. It is clear, however, that the service sector employs a wide range of staff, including professionals from a large number of academic backgrounds. This paper attempts to define the service sector, particularly on two important areas, the community services sector and the export industries sector. Community services are here defined as the education, health, welfare and justice areas that in total employ some $16 \%$ of the Australian workforce and provided some $11 \%$ in gross value added terms

Community services have been faced with a number of pressures over the last decade, such as National Competition Policy, downsizing, outsourcing, privatization, and reduced funding from governments. The export of services is of growing importance and service exports now represent $22.5 \%$ of total exports with travel and transportation contributing over $70 \%$ of these exports.

This paper identifies 20 priority research projects of which eight are in the area of community services and twelve focuses on the development of export service industries. Research areas addressed in community services include educational and training requirements, the development of a heath of the community services professions index, quality assurance and the monitoring of community services interventions, and the unintended outcomes flowing from downsizing, outsourcing and privatization. In the export services, research is needed on a more comprehensive data on export service industries, a National Export Services Strategy, and ways to maintain global competitiveness.

(Marta Soprana2011) This research looks at how competitive developing countries are in exporting services and at the instruments and tools that they can use to become credible competitors of developed economies in service exports. The analysis focuses on several case studies assessed by the existing economic literature, the lessons that developing countries can draw from those experiences, the role that enterprises, institutions and governments can play to increase the competitiveness of developing countries and the measures and tools they can use to achieve their objective.

The research aims at showing that a developing country could become competitive in service exports as long as it implements a series of measures aimed primarily at improving the country's human capital and infrastructures, making institutions play a more active role in assisting enterprises and governments and encouraging policymakers to adopt adequate policies in support of service exports. The measures change according to type of service, mode of supply, stakeholder and objective to be achieved. The research will also highlight the statistical limits and difficulties that countries, especially developing economies, face in properly assessing trade in services

(Ganeshan Wignaraja 2011) This paper analyses the link between commercial policies and exports through a comparative analysis of the Asian giants - the People's Republic of China (PRC) and India. While the PRC has surged ahead of India to dominate world manufactured exports, India has acquired competitive capabilities in skillintensive services. Favorable initial conditions such as large domestic markets and low-cost productive labor have laid the foundations for the giants' export success. While the gradual switch to market oriented commercial policies in the late 1970s drove trade-led growth in the giants, the PRC's reforms were swifter and more coordinated. It has introduced an open door policy towards foreign direct investment (FDI), actively facilitated technological upgrading through FDI, steadily liberalized a controlled import regime, ensured a competitive exchange rate, and concluded more comprehensive free trade agreements (FTAs) wit Asia's developing economies. India has attempted to develop more effective commercial policies since 1991, especially to attract FDI and liberalize imports. Therefore, one might expect the gap in trade performance 


\section{International Journal of Science and Research (IJSR) \\ ISSN (Online): 2319-7064 \\ Index Copernicus Value (2013): 6.14 | Impact Factor (2015): 6.391}

between the PRC and India to narrow over time. However, both giants face an uncertain world economic environment in the aftermath of the global financial crisis and future export success will depend on their evolving commercial policies. Critical issues that still to be resolved include how the giants will respond to the risk of protectionism, manage real exchange rates, and promote the use of FTAs among businesses, and increase in spending on infrastructure as well as research and development.

Rajshakhar G Javalgi, et al(2004) studied that advancement in information and communication technologies have created unprecedented opportunities to service provider both developing and developed countries .according to their research the services sector represented one of the fast growing areas of export in the global trade. Also the internet and e-commerce make it possible to sellarariety of services, ranging from airline tickets to financial services from anywhere in the world, around the clock. International delivery of services through electronic means is creating value in the supply chain by the reduction of money of the barriers to entry. Their paper focused on the determinants in flouncing the diffusion and export of e-services across borders. The paper also presented strategic challenges, followed by implications for service providers.

Vine Q. laet at (2005) in their research suggested that traditional export performances models, developed for and tested with manufacturing firms cannot be assumed to apply equally well in service settings. Further, they found that service specific export theory needs to adopt a contingency approach which in turn provides insightful and value-added research for academics and practitioners In the services exporting sector the paper provided recognition of the relative importance of the different export performances and value drivers; value position can be more effectively designed in order to gain competitive advantage.

\section{Methodology and data}

This chapter deals with methodology strategy under which I have carried out the research. "An Analysis of Impact of exports of commercial services on world exports of commercial services"

The variable used in this study of impact of selected countries commercial exports on world commercial services exports include world exports of commercial services (WEXP) as dependent variable and commercial services exports of United State of America (us), commercial services exports of France (Fr), commercial services exports of Netherland (nr), commercial services exports of Italy (it)

The sample period covers time series data from 2001 to 2011. All the relevant data is obtained from WTO statistics

\section{Implication of Stationary and non-stationary time series}

As we begin to develop models for time series, we want to know whether the underlying stochastic process that generated the series can be assumed to be invariant with respect To time. If the characteristics of stochastic process change over time, if the process is non-Stationary, it will often be difficult to represent the time series over past and future intervals of time by a simple algebraic model---the random walk with drift is an example of non-stationary process for which a simple forecasting model can be constructed. By contrast, if the stochastic process is fixed in time i.e. if it is stationary, then one can model the process via an Equation with fixed coefficients that can be estimated from past data. Observing the result of Unit-Root Test in the result section; it is clear that all the data series are Stationary at same level. So when data series are stationary, we can use the Ordinary Least Square Method to regress the series to get result. The method of ordinary least squares is attributed to Carl Friedrichgauss, a German mathematician. Under certain assumptions, the method of least squares has some very attractive statistical properties that have made it one of the most powerful and popular methods of regression analysis.

\section{Least Square Method for Regression}

Least squares or ordinary least square (OLS) is a mathematical optimization technique which, when given a series of measured data, attempts to find a function which closely approximates the data. It attempts to minimize the sum of the squares of the ordinate differences (called residuals) between points generated by the function and corresponding points in the data. specifically, it is called Least mean squares(LMS)when the number of measured data is 1 and the gradient descent method is used to minimize the squared residual.LMS is known to minimize the expectation of the squared residual, with the smallest operation.

\section{Method of sampling}

Secondary data regarding exports of commercial services was collected and for this purpose WTO statistics were contacted.

\section{Method of data collection}

For the study "an analysis of share of selected countries services exports on the world commercial services exports" the contribution of services exports of 4 countries was observed.

The topic was development economics so secondary data was collected and used extensively to assess the contribution of commercial services exports toward world exports commercial services.

Secondary data was collected from WTO Statistics department.

Table 3.2 Lists of Independent variables for regression model.

Table 3.2 explains developed countries of the world were considered as independent variables.

\begin{tabular}{|c|c|c|c|}
\hline \multicolumn{4}{|c|}{ Table } \\
\hline Countries & Independent & Countries & Independent \\
\hline USA & $\mathrm{X} 1$ & France & $\mathrm{X} 2$ \\
\hline Netherland & $\mathrm{X} 3$ & Italy & $\mathrm{X} 4$ \\
\hline
\end{tabular}




\section{International Journal of Science and Research (IJSR) \\ ISSN (Online): 2319-7064 \\ Index Copernicus Value (2013): 6.14 | Impact Factor (2015): 6.391}

4 developed countries of world were selected for regression analysis as, X1(commercial services exports of USA), X2(commercial services exports of France), X3(commercial services exports of Netherland), X4(commercial services of Italy).

$\mathrm{Y}=$ World commercial services exports.

\section{Model:}

- To test the relationship between World commercial services exports and different 4 developed countries commercial exports following model have been used:

- $\mathrm{WEXP}=\mathrm{f}$ (us, Fr, nr, it, u)

- WEXP: world commercial services exports

- US: commercial services exports of united state America

- Fr: commercial services exports of France

- Nr: commercial services exports of Netherland

- It: commercial services exports of Italy

Model specification:

- $\mathrm{WEXP}=\mathrm{BO}+\mathrm{B} 1$ (us) $+\mathrm{B} 2(\mathrm{Fr})+\mathrm{B} 3(\mathrm{nr})+\mathrm{B} 4($ it $)+\mathrm{Ui}$

\section{Quantitative analysis}

- For analysis of data the method used in this study is multiple regressions. Regression is used to check the impact of different independent variables on the dependent variable and also to test significance of this impact.

\section{Results and Discussion}

Results of unit root

This paper is an attempt to investigate the developed countries exports commercial services on world commercial exports. Secondary data for 11 years from 2001 to 2011 was used for this purpose. The first step in the empirical analysis involves testing the time series characteristics of the data series using ADF tests. Multiple linear regression and time series techniques are applied to estimate the relationship. The entire variables used in this study are stationary in their level.

\begin{tabular}{|c|c|c|}
\hline Variable & Level & \\
\cline { 2 - 3 } & Intercept and trend & Order of integration \\
\hline WEXP & $-3.44 * * *$ & $\mathrm{I}(0)$ \\
& $(-2.22)$ & \\
\hline Us & $-3.44 * *$ & $\mathrm{I}(\mathrm{O})$ \\
& $(-2.38)$ & $\mathrm{I}(\mathrm{O})$ \\
\hline $\mathrm{Fr}$ & $-3.44 * * *$ & \\
& $(-1.26)$ & $\mathrm{I}(\mathrm{O})$ \\
\hline $\mathrm{Nr}$ & $-3.44 * * *$ & \\
& $(-2.01)$ & $\mathrm{I}(\mathrm{O})$ \\
\hline $\mathrm{It}$ & $-3.44 * * *$ & \\
& $(-1.97)$ & \\
\hline
\end{tabular}

$*, * *, * * *$ denote the rejection of the null hypothesis at $1 \%$, $5 \%, 10 \%$ level of significance. Values in the parenthesis are 2Mackinnon critical values for rejection of hypothesis of a unit root.
Table 4.1: ADF Test Result of selected developed countries services exports and world commercial services exports

ADF test result of regression

\begin{tabular}{|c|c|}
\hline Independent Variable & Dependent Variable (WEXP) \\
\hline Constant & -664030.2 \\
& $(-13.230)$ \\
\hline US & 4.384 \\
& $(15.809)$ \\
\hline IT & 8.412 \\
& $(6.955)$ \\
\hline NR & 21.37 \\
& $(12.50)$ \\
\hline FR & -14.655 \\
& $(-8.347)$ \\
\hline R-Square & 0.999 \\
\hline
\end{tabular}

Regression estimated using data 2001 _ 2011 .Number of observations is 11 after adjusting points value are given below the coefficient estimate in each cell. There is a positive \& negative relationship between independent variable and Dependent Variable.

\section{Regression Output of commercial services} exports

\begin{tabular}{|c|c|}
\hline Variable & Coefficient \\
\hline C & $-664030.2^{* * *}$ \\
& $(50190.42)$ \\
\hline US & $4.384030^{* *}$ \\
& $(0.277311)$ \\
\hline IT & $8.412049^{* * *}$ \\
& $(1.209400)$ \\
\hline NR & $21.37902 * * *$ \\
& $(1.710099)$ \\
\hline FR & $-14.65542 * * *$ \\
& $(1.755599)$ \\
\hline R-squared & 0.999753 \\
\hline
\end{tabular}

$*, * *, * * *$ denote the rejection of the null hypothesis at $1 \%$, $5 \%, 10 \%$ level of significance. Values in the parenthesis are 2 Mackinnon critical values for rejection of hypothesis of a unit root.

Independents variables are significant in this model, as it has positive impact on dependent variable WEXP instead independent variable $\mathrm{Fr}$, as it has negative impact on dependent variable WEXP. All independents and dependent variables are totally insignificant, as the p-value of all variable are less than 5\%. It means, we accept the null hypothesis and reject the alternative hypothesis. R-squared is more than $95 \%$ which indicate the goodness of the model. It means that the overall model is best for future demonstration because of $\mathrm{R}$-squared value is $99 \%$. So we reject null hypothesis and alternative hypothesis.

At last the result model shows that dependent and independent variables are highly significant to each other. There is a positive \& negative relationship between independent variable and dependent Variable.

\section{Summary, conclusion and Recommendations}

\section{Summary}

This paper is an attempt to investigate the impact of selected countries exports commercial services o $\mathrm{n}$ World commercial services exports. For this purpose I used the 


\section{International Journal of Science and Research (IJSR) \\ ISSN (Online): 2319-7064 \\ Index Copernicus Value (2013): 6.14 | Impact Factor (2015): 6.391}

secondary data for 11 year from 2001 to 2011. The data was taken in millions; it was taken as it is according to WTO statistics. Multiple regression time series techniques were applied to estimate the relationship. In result developed countries united State, Netherlands, Italy and France are negatively influencing the world exports of commercial services. Because dependent variable has negatively sign (with its dependent variable coefficient C), so this relationship is negatively correlated to the independent variables united State, Netherlands, Italy and France .p value 0.0000 and highest $\mathrm{R}$-square value $99.9 \%$.

\section{Conclusion}

Four selected developed countries have negative impact on total world exports. These countries are spending much more for their people but not extra expenditure for foreign trade. These countries are not taken much import goods for their needs from other countries. These countries are well established and do not need good and services from other countries

\section{Recommendations}

I wish to suggest the following step in order to improve the exports of commercial service export. Many developed countries have the potential to become exporters of BPO services, tourism, health- and education-related services because they have the basic resources upon which these services are founded: an abundant labor force, impressive artistic and natural resources, adequate language skills and strong historical linkages with their target markets. It is suggested for these countries to increase their expenditure according to benefit other countries. Consumer friendly policy must be projected

\section{References}

[1] Bd Jordan, 75014, Paris, France. Between Greece and Iran" South-Eastern Europe Journal of Economics 1 (2012) 53-66

[2] Bhagwati, J., Panagariya, A., and Srinivasan, T.N., (2004). 'The Muddles' over Outsourcing', Journal of Economic Perspectives, 18(4): 93-114.

[3] Carolina Lennon WORKING PAPER N 2008 - 52 "Trade in services and trade in goods: Differences and complementarities JEL Codes: F12, F15, L8 University of Paris 1 (Pantheon-

[4] Challenges according to mode of supply

[5] Copeland, Brian, and Aaditya Mattoo. 2008. "The Basic Economics of Services Trade.” In A Handbook

[6] Ganeshan Wignaraja 2011The People's Republic of China and India: Commercial

[7] General Agreement on Trade in Services. The Results of the Uruguay round of Multilateral Negotiations: the Legal Text, appendix IB, 1995

[8] Holger Breinli chChiara Criscuoloz March 2009International Trade in Services: A Portrait of Importers and

[9] http://www.computereyez.co.uk/links/glossary.htm

[10] http://www.eubusiness.com/europe/France

[11] http://www.eubusiness.com/europe/itlay

[12] http://www.eubusiness.com/europe/netherlands
[13] http://www.infoplease.com/country/united states.html?pageno=2\#ixzz2qXy7wCX6

[14] LaelBrainard and Susan M. Collins, 1-34.Washington, DC: The Brookings Institution.

[15] Langhammer, Rolf J. (2000) : Developing countries as exporters of

[16] Markusen, J. R., 2005. 'Modeling the Off shoring of White-Collar Services: From Comparative Advantage to the New Theories of Trade and Federal Direct Investment', In Brookings Trade Forum 2005: Off shoring White-Collar Work, ed.

[17] Marta Soprana(2011) Services exports and developing countries: competitiveness

[18] of International Trade in Services, ed. Aaditya Mattoo, Robert M. Stern, and Gianni Zanini, 84-129.

[19] Particularly for Community Service Professions and Export Services Business/Higher Education Round Table A.C.N. 050207942

[20] Policies in the Giants No. 83 |

[21]Professor Millicent E Poole, John C Wood2003Research Issues for the Service Sector,

[22] Rajshakhar G Javalgi, et al(2004) Export of e-services in the age of technology transformation: challenges and implication fpr ISP. Journal of S Marke voi 18 ISS:7 pp560-573.

[23] Reeti Gupta (2012) “Dynamics of India's Commercial Service Exports" American International Journal of Social Science Vol. 1 No. 2; services: looking beyond success episodes, Kiel Working Papers, No. 992

[24] Sujinda Chemsripong, (2008) Services Exports: An Evolution and Evaluation of Thailand's Services Volume 7, Number 9

[25] Susanna Lundstrom Gable Saurabh Mishra 2011 Service Export Sophistication and Europe's New Growth Model Policy Research Working Paper Washington, DC: World Bank; New York: Oxford University Press.

[26] Vinh Q. laet at (2005) Determinants of export performance across services type: a conceptual model" Journal of sm vol 19 iss 6 pp 379-371. 